\title{
The Origin and Development of English Novel: A Descriptive Literature Review
}

\section{Choeda}

Department of Language Education, Samtse College of Education, Bhutan. choeda.sce@rub.edu.bt

\begin{abstract}
Novel as a literary genre enjoyed the highest level of glory in the $18^{\text {th }}$ century. The authors namely Defoe, Richardson, Fielding and Sterne contributed significantly to the development of English novel. They influenced the writers who came after them. The $18^{\text {th }}$ century coincided with the industrial revolution which significantly contributed to the rise of the novel (with the invention of printing machine). The chain effects of industrial revolution improved people's life and living standard. The rise of the educated middle class people further increased the reading public which correspondingly led to demand of novels for reading. Books such as 'Don Quixote', 'Decameron', 'Morte d' Arthur' and 'Pilgrim's Progress' laid the foundations for the development of the novel. 'Pamela', 'Joseph Andrew's, 'Tristram Shandy', and 'Robinson Crusoe' were some of the notable books that became famous in the $18^{\text {th }}$ century. However, novels continued to evolve in the $19^{\text {th }}$ and $20^{\text {th }}$ century giving rise to different genres or classes of novel. Keywords-Bunyan, Defoe, Epistolary novel, Fielding, Origin of the novel, Picaresque tradition, Rise of the middle class, Sterne.
\end{abstract}

\section{INTRODUCTION}

This paper is written for undergraduate students particularly English and Literature students who may have to study the historical developments of novel in general or $18^{\text {th }}$ century novel or literature in particular. It is aimed at providing overview of how the novel as genre of literature originated and gained popularity. The paper starts with forerunners or antecedents of the novels to establish the context of the rise of the novel. The origin of the novel is then traced back to the world's oldest literature, the epics, followed by discussion on the romances which ultimately led to birth of novel proper. The paper also describes different types of novels such as picaresque and epistolary which were the foundations of the novels. The last segment of the paper presents brief summary of the different types of novels that evolved post $18^{\text {th }}$ century.

\section{THE ANTECEDENTS OF THE NOVEL}

Though English novel as a literary genre gained popularity in the eighteenth century, its beginning can be traced back to 612 BC when world's oldest literature Epic of Gilgamesh was written. Homer, who lived in 700 or $800 \mathrm{BC}$, was the first notable poet or a literary pioneer who wrote the famous Greek epics, The Iliad and The Odyssey. He established the tradition of epic which had particular structure and subject matter. In 900 BC Roman poet Virgil produced epic poems Beowulf and Aeneid with the latter becoming a model for John Milton (1608-
74) to write his Paradise Lost. The epics were narrative verses telling stories of human encounters with monsters and accounts of accomplishments of heroic deeds in battles.

After the epics came a new form of literature called the romances originating in France in the $12^{\text {th }}$ century. It was also popularly known as chivalric romance or medieval romance (having flourished in the medieval times or medieval age between 1000 AD to 1450 AD). The scholars deviated from the tradition of epic by choosing subjects such as bravery, honour, adventure and courtly love with unique features of using magic, spells and enchantments in the romances to arouse curiosities and interests in the readers. According to Abrams, (1995) "Romances were first written in verse, but later in prose as well" (p.22). One of the notable English romance is Malory's Morte d'Arthur written in prose (in about 1470) which accounted the legend of King Arthur and his Knights of the Round Table.

Geoffrey Chaucer (1343-4000) used both verse as well as prose in The Canterbury Tales (CromptonRickett, 1995). Among the 24 stories included in The Canterbury Tales, two stories, the 'Tale of the Melibeus' and the 'Parson's Tale' were written in prose. He had also included a romance, The Knight's Tale. However, it was Chaucer's long poem Troilus and Criseyde (written in about 1380) which introduced new characteristics of literary tradition with the use of plot and conversations in the poem. Chaucer gave "a new turn to fiction" (Roy, 
2016, para, 2) for social and religious aspect of life were portrayed in the stories unlike farfetched realities of romances.

Even before Malory and Chaucer, Boccaccio (13131375), an Italian author had already started to write in prose in 1350. Boccaccio produced "prose tales of amorous adventure, The Decameron" (Compton- Rickett, 1995, p. 105). That's why, Italy is considered as the home of the novel. Chaucer was influenced by Boccaccio's style of storytelling.

The popularity of the romances remained in vogue till 1600 when a new literary style in the form of burlesque came to existence. The writers wanted to mock and bring fun out of serious literary matter. For instance Cervantes made fun of the medieval romances by writing the famous Don Quixote (1605). Unlike the original romances in which the knights fought with giants and dragons to save damsels in distress, his knight (Don Quixote) fights with windmills which he sees as giants bringing laughter to the readers. Alongside the burlesques literary style came the picaresque tale which was already in fashion in Spanish literature since the anonymous publication of Lazarillo de Tolmes (1554). The word picaresque was derived from Spanish word 'picaro' meaning a rogue. In a picaresque tale, the main character is a rogue or rascal who goes on an adventure and leads his life by his wits. The element of adventure of the picaro influenced later novelist such as Mark Twain and Saul Bellow who wrote Huckleberry Finn and The Adventures of Augie March respectively.

In 1688, a short prose work titled Oroonoko, or the History of the Royal Slave written by female author Aphra Behn (1640-89) was published. Behn was influenced by the quest of knights in chivalric romances in which a knight goes in pursuit of his ladylove overcoming dangers and the difficulties. Oroonoko, a prince goes on a visiting mission of his deceased army general's daughter Imoinda following which they fall in love. However, soon he meets with hurdles planned by his king who blocks his marriage. The story was constructed in a form of biography following a linear plot. Behn contributed towards depicting the truth of life and the book was an "attack on what she (perceived) as the moral distant colonial problem of human slavery, degradation and suffering" (Sanders, 1994, p.269).

Another work of prose was produced by Behn's contemporary John Bunyan (1628-1688) who published Pilgrim's Progress in 1678 and The Life and Death of Mr. Badman in 1680. Pilgrim's Progress was the best seller during that time for every household owned a copy of it. It is religious allegory telling the story of Christian who undertakes a pilgrimage from his home in the city of destruction (world) to the celestial city (heaven). Coincidentally the elements of modern day novel such as settings, characters, and conflicts were used well to present the journey of Christian. "The ideas of repentance, of faith, of resisting temptation, and of perseverance" (Kuiper, 2012, p.4) that Christian goes through in the story are the elements of the modern novels such as beginning, conflict, the rise in action, fall in action and resolution. According to Bora (n.d) Bunyan's Pilgrim's Progress "provided an important model for story-telling, with vivid characterization and recording of dialogue which influenced a lot of later novelists" (p.4).Thus at the dawn of the eighteenth century, the foundation for the development of novel as a new genre of literature was well established paving way for the rise of the novel.

Besides exploring the forerunners of the novel such as epics, poetry and romances to gather overview of how development of novel progressed until the $18^{\text {th }}$ century, it is necessary to understand the origin of the word 'novel' itself.

\section{DEFINITION AND ORIGIN OF NOVEL}

According to The Shorter Oxford Dictionary, novel is "a fictitious prose narrative of considerable length in which characters and actions representative of real life are portrayed in a plot of more or less complexity" (cited in Rees, 1973, p.106). Another definition by an anonymous author states that a novel is "a piece of prose fiction of a reasonable length". Both the definitions highlight the word 'prose' meaning the common or ordinary spoken form of language without the presence of poetic rhythmic structure. However, there are a few novels written in verse as well, such as Vikram Seth's The Golden Gate and Alexander Pushkin's Eugene Onegi. The other aspect of the definition is related to the length. The first definition points out 'considerable length' and second definition states 'reasonable length' to distinguish the novel's unique feature as a genre vis a vis genre of short story. The lengths of some novels are similar to the length of short stories and hence a term such as 'novella' is often used for shorter novels.

The word novel is considered to have been derived from the latin word novellus, Italian word novella (which meant a little new thing) and French word novelle. It was Boccaccio who first used the term novella storia (short tale in prose) when he first experimented writing prose. Boccaccio popularized the vogue of collections of novella with his collection of ten short stories titled Decameron in fourteenth century. However, the meaning of the word 
novel meant the kind of short stories written and collected by Boccaccio until the $17^{\text {th }}$ century. With the rise in the development of novels in the $18^{\text {th }}$ century the meaning of the word novel underwent change from short tale in prose to 'prose narrative of considerable length' as stated by The Shorter Oxford Dictionary.

Thus with understanding of the definition of novel, it is relevant to discuss what factors or situations provided opportunities for the rise of the novel in the $18^{\text {th }}$ century.

\section{RISE OF NOVEL IN THE $18^{\mathrm{TH}}$ CENTURY}

Majority of the literary critics attribute $18^{\text {th }}$ century as the time period in which novel took its birth, subsequent growth and development. With adequate literary predecessors such as Bunyan, Behn, Chaucer, Malory, Cervantes, Boccaccio and numerous other writers of the $17^{\text {th }}$ century, the $18^{\text {th }}$ century writers availed opportunities to further experiment and produce novel as a literary genre. Further the increase in literacy rate, industrial revolution, rise in the middle class and coming up of libraries created favourable situations for the rise of the novel. In the new form of literature namely the 'novel' the construct of the story departed from the romance and attempted at verisimilitude depicting the pragmatism and morality of the middle class people. Alexander Pope's dictum, "The proper study of mankind is men" influenced the interest of the people to study human character. Thus $18^{\text {th }}$ century novels explored human characters with the novelist creating real life characters in their novels unlike giants, dragons and super human characters in the romances.

\section{FACTORS THAT INFLUENCED THE RISE OF THE NOVEL}

\subsection{Industrial revolution}

One of the major factors that contributed to the rise of the novel is the development in industries. With machinery work could be done faster and people could get more time for rest and leisure time during which people resorted to reading novels. Printing press were available for production of multiple copies at cheaper rate. Even low income people could afford to buy and read books unlike in the past when only aristocrats were the reading public. Besides variety of reading materials such as newspapers, novels and magazines were made easily available due to printing press. The newspapers and magazines helped develop the habit of reading which ultimately led people to start reading novels. Some of the novels were also published in magazines increasing the access to novels besides the book form. According to Hasan (2015), the industrial revolution "paved the way to the rise of the middle class people" (para.2) who created demand in the reading materials for they had plenty of leisure time. With manual work being done by machines, people could get a lot of free time for reading. Further they had desires to read about "their everyday experiences" (Hasan, para.2) which prompted authors such as Daniel Defoe, Samuel Richardson and Henry Fielding to write prose fictions depicting real life experiences.

\subsection{Decline of romance and drama}

Since romances were mainly suitable to be read by elite, aristocratic or noble families, it could not sustain the readership. The common people got bored with romances for they had no relevance of any sort to them. In addition, the stories themselves being centuries old were no longer of interest to the people. The settings in which the stories in the romances took place were also unrealistic. Therefore, romances as a literary genre started to decline. People started to take interest in the contemporary issues. Unlike romances, the novels were written in first person (making it appear 'more personal and recent') with ordinary characters that the readers could relate with.

Decline of drama was also one factor that promoted the rise of the novel. In the $17^{\text {th }}$ century, during the rule of Cromwell, theatres (which were so popular during the Elizabethan times) were banned (Shah, n.d). Moreover, novel could reach vast audience when theatre could reach only to a limited audience. When drama came back with the restoration age, it could not establish its essence since novels got well established then.

\subsection{Rise of the middle class}

One outcome of industrial revolution was the rise of middle class. The growth in industries brought about unprecedented corresponding growth with trade and commerce. The people were increasingly becoming wealthy with even poor people of lower rung being able to raise their status. Therefore, the additional newly attained middle class status, this group of people started behaving like the traditional landed gentry demanding books to read. Further, with improved living standard many (both men and women) could acquire education and be able to read. Women readers increased with greater leisure time with the rise of middle class and it was a fashion for high status women to remain engaged in reading literature. Further the new group of middle class people did not like the traditional medieval stories of the knights. According to anonymous article titled, 'Reasons for the rise of the novel in the eighteenth century' in the web blog Naeem Educational Organisation (NEO) the rising middle class people demanded a new type of literature which conformed to their temper and taste and 
"took little interest in the exaggerated romances" (2010, para.4). Thus the novelist wrote about common people revealing the "the psyche of the middle class" (para.4) in their novels. Defoe's Robinson Crusoe, Richardson's Pamela, and Fielding's Tom Jones were appealing to the readers.

\subsection{Mobile libraries}

The start of mobile libraries facilitated the increase of reading public. Reading was promoted by providing easy access to books with books being brought to the homes if people joined the mobile library as members. Women readers benefited a lot since they used to stay at home and exchange books after they finish reading one (Shah, n.d) from the mobile library.

Though industrial revolution, decline in romance and drama, rise of the middle class and mobile libraries played significant role in the rise of the novel, four authors namely Defoe, Richardson, Fielding, and Sterne took the novel to "the highest point of glory" (Roy, 2016, para.8).

\section{PIONEERS OF THE NOVEL}

\subsection{Daniel Defoe (1660-1731)}

Daniel Defoe was born in London. He was a merchant, a manufacturer, a public official and an editor before becoming a writer at the age of fifty eight (Compton-Rickett , 1995). Robinson Crusoe, his first book was published in 1719 followed by Moll Flanders in 1722. Defoe is considered to be "the first true master of English novel" (Sanders, 1994, p.307). It was he who introduced the 'journalistic first person narrative' creating fiction to be a fact to the readers. He was the first writer to have introduced the technique of realism. Despite the story of Robinson Crusoe, the character being fictitious, the style of first person narration brought out the element of realism. Though the novel had no real plot but just an account of chronological sequences of events, Baker, a literary critic considered Robinson Crusoe to be the first modern novel. Defoe is also called as the founder of the modern novel. However, some critics have categorized Defoe's work as work of romances since the element of adventure and crime dominated. Still, later novelists who wrote autobiographical novels were influenced by Defoe's style.

\subsection{Samuel Richards on (1689-1761)}

Samuel Richardson was born in 1689 in Derbyshire in London. He worked as a printer of the Journals of the House of Commons and Law Printer to the King. During his youthful stage he had experiences of writing love letter for three girls through which he understood the ways of femininity and utilized the same knowledge in his epistolary novel Pamela or Virtue Rewarded published in 1740. Richardson believed that the novelist had dual purpose of writing novels; to inform the readers and impart morality. The whole of the novel of Pamela or Virtue Rewarded is the exchange of personal letters between the girl Pamela and her parents. The narrator Pamela, a servant girl employed in a rich land owner informs her parents through a series of letters how she maintains her virtue amidst her employer's inappropriate advances until he proposes a marriage. Richardson had been credited to have created novel of character by exploring the psychological development in Pamela. In contrast Defoe explored the physical development of character in Robinson Crusoe. Clarissa or the History of Young Lady and The History Sir Charles Grandison were additional novels written by Richardson in same epistolary mode. He influenced and popularized the feature of sentimentality in English novels (Roy, 2016).

\subsection{Henry Fielding (1707-1754)}

Henry Fielding was born at Sharpham Park near Galstonsbury in 1707 (Compton- Rickett, 1995). He studied law. Fielding is considered as the father of English novel. He was influenced by picaresque tradition of writing. He is known for novels such as Shamela, Joseph Andrews (1749) and Tom Jones (1742). He popularized the aspect of "realism, characterization and craftsmanship" of novel (Roy, 2016, para. 8). Through his novel he presented "a true and realistic picture of human nature" (Kettle, 1967, p.71). Fielding's first novel was Shamela written as a parody to Richardson's Pamela for he considered it to be hypocritical morality. In doing so he popularized comic novel. He continued to mock at Richardson's Pamela by presenting a contrasting situation with a young man Joseph being pursued by a rich lady in Joseph Andrews. Fielding thus laid foundation for comic novels.

\subsection{Laurence Sterne (1713- 1768)}

Laurence Sterne was born in 1713 at a place called Clonmel in Ireland. He graduated from Cambridge and became a priest. Sterne's approach to writing novels was far different and unique compared to his contemporaries. He experimented writing novels in a different style rather than the conventional method with beginning, middle and end. Rajimwale (2004) remarked that he "was different and remote from the major novelists of his time" (p.224). In his novel Life and Opinions of Tristram Shandy, Gentlemen (published in nine separate volumes between 1759-1767) Sterne employed autobiographical but non linear narrative techniques by frequently skipping and jumping ahead of time and shifting back in time creating 
fragmented narration. The main character or the narrator Tristram Shandy is born only in volume IV. Unlike his contemporaries who had definite plot and structure with beginning, middle and end, Sterne's novel had no definite plot. Instead it begins in the middle, get intercepted with devices such as digressions, humorous reflections and deliberate blank pages kept in the middle of the story for the readers to fill in and respond. According to OganaRoxana (2010), Tristram Shandy does not satisfy the usual expectations of how a novel should be organized (para.9). However, Sterne "introduced a method of progression by sensory suggestion and momentary reaction to immediate experience" (Bora, p.8) which influenced modern writers such as Joyce and Woolf who used stream of consciousness as narrative technique.

\section{OTHER IMPORTANT AUTHORS}

Tobias Smollett (1721-1771) was also an influential novelist of the time. He was known for writing satire and describing the "familiar scenes, follies, foibles and knavery of the ordinary life" (Rajimwale, 2004, p.223). He also used picaresque style in his novels, The Adventures of Roderick Random (1748) and Gilbas (1715-1735).

Jonathan Swift (1667-1745) was known for satire and allegory. A tale of a Tub (1704) and Gulliver's Travels (1726) were both allegorical novels. Swift introduced the use of the story of fantasy as a satire to reveal weakness in the society through his novels.

\section{KEY FEATURES OF $18^{\mathrm{TH}}$ CENTURY NOVELS}

The writers of the $18^{\text {th }}$ century bought out realism. The novels were instruments to explore and represent the reality of the society. The authors used verisimilitude with books imitating the real life of the people. The use of first person narrative technique created the element of realism. Further, unlike the romances, characters in the novels were ordinary men and women with settings familiar to the readers. In addition, the focus of the protagonist was given on middle class people. The purpose of the novel was mainly to promote virtuous character in people just as Richardson did. Some authors such as Swift and Smollett used satire and allegory to point out the vices in the society. The pioneer novelists contributed unique aspect of novel; Fielding popularized epic novels, Richardson with epistolary and sentimental novel, Defoe with realistic novel, Swift with satirical and philosophical novel and Sterne with experimental novel.

Thus $18^{\text {th }}$ century novelist gave the novelist of the time fresh avenues and flexibility for writing novels without having to follow established tradition as classical writers were bound to. It was an age of revolution and experimentation of writing novels which promoted further experimentation and creativity giving rise to subgenres or different genres of novel in the post $18^{\text {th }}$ century.

\section{POST $18^{\mathrm{TH}}$ CENTURY NOVELS}

In the $19^{\text {th }}$ century which came to be known as age of romantic poets or return to the nature. The romantic poets generated the idea of nature as a source of inspiration besides being a teacher, guide and mother unlike $18^{\text {th }}$ century poets who treated nature as normal reality. It was marked by 'love of nature', 'love of medieval age' and 'love of supernatural' (Amin, 2012). When $18^{\text {th }}$ century writers placed value on realism and rationality, the romantic writers stressed their value on imaginations and emotions. The setting and themes of the medieval romances were once again picked by $19^{\text {th }}$ century writers to create their fictional work. Castle of Otranto was the first novel to have made used of the elements of ghost which was based on medieval romance. So due to change in the ideology, different genres or classes of novel got developed in the $19^{\text {th }}$ and $20^{\text {th }}$ century.

\subsection{Novel of manners}

Some ideas of the romantic poetry influenced the novels, particularly the cult of feelings known as sensibility (Rajimwale, 2004). Jane Austen (1775-1817) considered sensibility in women to be revealing weakness of womanhood and deplored it. She was one writer who presented detail portrayal of how women's behaviours were being determined and influenced by inner sensibility. Her novels were all centred on women describing the customs, values and mores of the society during her time. She wrote Pride and Prejudice (1796), Sense and sensibility (1797) and Mansfield Park (1814).

\subsection{Historical novels}

Sir Walter Scott (1771-1832) introduced historical novel. As per Albert (1979), Scott "added a life-giving force, a vitalizing energy, an insight, and a genial dexterity that made the historical novel an entirely new species" (p.340). Rob Roy (1817) and Ivanhoe (1820) were few of the popular historical novels he had written.

\subsection{Chronicle novel}

Emma (1815) written by Jane Austen and Jane Eyre (1847) by Charlotte Bronte (1816-1855) are examples of chronicle novels for they provide narrative accounts starting from their early childhood till their adulthood. The events that happen in the novel are connected with dates.

\subsection{Gothic novel}


In gothic novels, authors use the element of supernatural with appearance of ghost, revealing tombs and dungeons creating the feeling of horror. The first gothic novel to have been written was the Castle of Otranto (1764) by Horace Walpole (1717-1797). Emily Bronte (1818-1848) had made use of gothic element in her novel Wuthering Heights (1847) in which the ghost of Catherine appears.

\subsection{Regional Novels}

The genre of regional novel is associated with Victorian writer Thomas Hardy (1840-1920). In regional novels, recognizable region or place is presented. Hardy has created a region called Wessex (an imaginary place) as setting of his novel. That's why sometimes his novels are called as Wessex novels. His popular novels are the Return of the native, Mayor of Casterbridge and Tess of the d'Urberville. Indian author R K Narayan (19062001) also created a society called Malgudi which appeared as setting for most of his stories and novels. The Guide is a popular novel written by Narayan

\subsection{Stream of consciousness novels}

James Joyce (1882-1941) and Virginia Woolf (1882-1941) are two important authors who made use of stream of consciousness narrative technique in their novels. They believed that reality is presented through showing than telling. How the feelings are experienced by characters subjectively are important rather than relying on somebody from the outside to make commentary and tell the story. The narration depends on the interior monologues or interior flow of thoughts which are often disjointed and non linear unlike traditional linear narration of events. Inner working of the mind of the character is given importance, which is the actual reality. Joyce's Ulysses (1922) and Woolf's To the Lighthouse (1927) are examples of stream of consciousness novels.

\section{LIMITATIONS}

To understand and get the overview of the rise of the novel in $18^{\text {th }}$ century, one needs to trace back to the origin as well as look ahead or even beyond the 18th century. This is because of the fact that the readers are already in the $21^{\text {st }}$ century. It becomes necessary to get overall understanding of how the development of novels started and evolved in the process to reach the present form. However, due to the extensive nature of the topic, many notable authors and novels despite being important are being left out. Therefore, it is important that one take the ideas from this paper and explore further to enrich one's understanding of the development and rise of English novels.

\section{REFERENCES}

[1] Abrams, M.H. (1978). A glossary of literary terms. Madras: Macmillan India Limited.

[2] Albert, E. (1979). History of English literature $\left(5^{\text {th }}\right.$ ed. New Delhi: Oxford University Press.

[3] Amin, M.A. (2012). The English romantic movement “ as return to nature. Or, the main features of romanticism. [Blog post] Retrieved

from http://24study.blogspot.com/ 2012/07/ the-englishromantic-movement-as-return.html

[4] Bora, M. (n.d). Back ground to the rise of the novel. Retrieved from

http://epgp.inflibnet.ac.in/ep gpdata/uploads/epgp_ontent/S 000013EN/P001447/M017744/ET/148736627Paper02\%3 BModule26\%3BEtext. pdf

[5] Compton-Rickett, A. (1995). A history of English literature. New Delhi: UPS

[6] Publishers' Distributers Ltd. (Reprint version, Date of original year of publication missing))

[7] Hasan, M.N. (2015). The eighteenth century and the rise of the English novel. International Journal of Literature and Art, 3 (2), 18-21. Doi:10.11648/j.ijla.20150302.12

[8] Kettle, A. (1967). An introduction to the English novel. New Delhi: Universal Book Stall.

[9] Kuiper, B. (2012, March 23-24). Pilgrim's progress: How a novel can affect an entire culture's communication. Paper presented at Faith and Communication Conference, Campbell University, North Carolina.

[10] Naeem Educational Organisation, (2010). Reasons for the rise of the novel in the eighteenth century [Blog post]. Retrieved from http ://neoenglishsy stem.blogspot.com/2010/1/reaons-forrise-of-novel-in-eighteenth.html

[11] Ogana-Roxana, I. (2010). Tristram Shandy: An original and profound English novel of the eighteenth century. Retrieved from https://pdfs.semanticscholar.org/1e02/8a611a18bd 4f862ab09c3a0117c4566b842.pdf

[12] Rajimwale, S. (2004). A history of English literature. New Delhi: Rama Brothers India Pvt Ltd. Rees, R.J.(1973). English literature: An introduction for foreign readers. Delhi: Macmillan India Limited.

[13] Roy, H. (2016, December, 26). Development of English novel in the $18^{\text {th }}$ century [Blog post].Retrieved from https://roy hareshwarroy .blogspot.com/2016/12/traedevelopment-of-english-novel-in.html

[14] Sanders, A. (1994). The short oxford history of English literature ( $3^{\text {rd }}$ ed.).New Delhi: Oxford University Press.

[15] Shah, U. (n.d). Factors that gave rise to English novel. Retrieved from http://www.academia.edu/9198958/Factors_that_give_rise_ to_English_Novel 